\title{
Transmitter-Replacement Therapy in Alzheimer's Disease Using Intracerebroventricular Infusions of Receptor Agonists
}

\author{
S. Gauthier, R. Leblanc, R. Quirion, G. Carlsson, M. Beaulieu, R. Bouchard, \\ D. Dastoor, F. Ervin, L. Gauthier, M. Gauvin, J. Henry, R. Palmour and Y. Robitaille
}

\begin{abstract}
Neurotransmitter replacement therapy in Alzheimer's Disease is currently being attempted using bethanechol chloride (Urecholine) infused intracerebroventricularly with an Infusaid continuous infusion pump. The rationale of this therapy is based on the severe cortical pre-synaptic cholinergic deficit in the presence of relatively normal post-synaptic muscarinic receptor density. Patients are selected on the basis of strict clinical criteria at a functional stage 4 or 5 of Reisberg. A cortical biopsy at the time of pump and catheter implantation confirms the diagnosis by histological and biochemical examination. Pre-operative, post-operative and serial mental status assessments combined with functional ADL assessments monitor changes in behavior. A 6 months double-blind treatment period is done in every patient, who is then free to continue if he has improved on active treatment. This specific study is part of a multi-centre trial. Other therapeutic trials using somatostatin analogs, such as Sandostatin, could then be done. The biological effects of the latter compound are being studied currently in adult Green Vervet monkeys, prior to its use in Alzheimer patients. Furthermore autoradiography of bethanechol and peptides labeled with ${ }^{14} \mathrm{C}$ administered in these animals by intracerebroventricular infusion will allow a better knowledge of their pharmacological site of action.
\end{abstract}

RÉSUMÉ: Rapport intérimaire sur le traitement substitutif par neuromédiateur dans la maladie d'Alzheimer au moyen d'infusions intracérébroventriculaires de substances agonistes des chémorécepteurs. Des tentatives de traitement substitutif par neuromédiateur dans la maladie d'Alzheimer sont actuellement en cours au moyen d'une pompe à infusion continue de type "Infusaid"' injectant du chlorure de béthanecol (Urecholine) au niveau du système ventriculaire cérébral. Cette thérapie est basée sur l'observation d'un déficit cholinergique sévère au niveau pré-synaptique dans le cortex alors que la densité des récepteurs muscariniques au niveau post-synaptique est relativement normale. Les patients sont chosis à l'aide de critère cliniques rigoureux alors qu'ils sont à un stade fonctionnel 4 ou 5 à l'échelle de Reisberg. Le diagnostic est confirmé par un examen histologique et biochimique de tissu cérébral prélevé par biopsie au moment de la mise en place du cathéter et de la pompe à infusion. Des évaluations de l'état mental en période pré-opératoire, post-opératoire et à intervalles fixes par la suite, associées à des évaluations fonctionnelles de type "ADL" sont utilisées pour surveiller les changements de comportement des sujets. Chaque patient est soumis à une période de.traitement en double-insu de 6 mois; il(elle) est ensuite libre de continuer s'il y a eu amélioration de son état pendant la période de traitement actif. Notre étude fait partie d'un programme d'essais thérapeutiques multi-centres. D'autres essais thérapeutiques avec des analogues de la somatostatine, tel que le "Sandostatin", pourront ensuite être faits. Les effets biologiques de cette dernière substance sont présentement à l'étude chez les singes "Green Vervet", avant son essai chez les patients atteints de la maladie d'Alzheimer. De plus, des études autoradiographiques faites à l'aide de béthanechol et de peptides marqués au ${ }^{14} \mathrm{C}$ administrés par infusion intracérébroventriculaire à ces animaux nous permettront de mieux connaître leur site d'action pharmacologique.

Can. J. Neurol. Sci. 1986; 13:394-402

From the Montreal Neurological Hospital and Institute (Drs. S. Gauthier, Leblanc, Robitaille, and Gauvin); the Douglas Hospital Research Centre (Drs. Quirion and Dastoor); Intermedics Infusaid Inc. (Dr. Carlsson); Sandoz Canada Research Department (Dr. Beaulieu); the Hospital de I'Enfant Jesus (Dr. Bouchard); the Allen Memorial Institute (Dr. Ervin, Henry and Palmour); the School of Physical and Occupational Therapy, McGill University (Dr. L. Gauthier) and the Toronto General Hospital (Dr. McLachlan)

Reprint requests to: Dr. S. Gauthier, Montreal Neurological Institute, 3801 University Street, Montreal, Quebec, Canada H3A 2B4 
Specific neurotransmitter systems are altered in patients with Alzheimer's disease. These include the cholinergic system originating from the Nucleus Basalis of Meynert and innervating large areas of the cerebral neocortex ${ }^{1}$ and somatostatincontaining cortical neurons. ${ }^{2}$ There is lesser and variable involvement of serotonin, ${ }^{3}$ noradrenaline ${ }^{4}$ and possibly corticotropin-releasing factor ${ }^{5}$-containing neurons.

Until the genetic basis for the expression of Alzheimer's disease is known and controlled by molecular pharmacology, or until embryonic cells can be implanted successfully, pharmacological neurotransmitter replacement therapy will continue to be of interest in the management of this condition.

Treatment using dietary precursors such as choline ${ }^{6}$ and lecithin, ${ }^{7}$ physostigmine ${ }^{8}$ and more recently direct muscarinic agonists such as bethanechol ${ }^{9}$ has been attempted. These agents were administered orally or subcutaneously, with little clinical response. Harbaugh et al in $1984^{10}$ demonstrated the feasibility of continuous intracerebroventricular (ICV) infusion of bethanechol chloride using a subcutaneously implanted pump (Intermedics Infusaid Inc.) connected to a ventricular catheter. This avoids extracerebral muscarinic side effects and allows titration of the daily dose infused. Extrapyramidal rigidity and nausea were noted in some patients but both were reversible with alterations of the dose. Our group joined a multi-centre study to evaluate ICV infusion of bethanechol in a large number of Alzheimer patients in a double-blind cross-over study over a six month period. We report here the base-line clinical, functional and laboratory data on our nine patients, who will complete their treatment protocol in November 1986.

\section{Patient Selection}

Inclusion criterias selected patients with a clinical diagnosis of "probable Alzheimer's disease",11, intermediate stage, living with an adult who could observe and report changes in activities of daily living. Informed consent was obtained from patients and closest relatives.

Table 1 summarizes the clinical features of our nine patients. All had onset of symptoms prior to age 65 and they are of mixed ethnic, educational and geographical origin. A positive family history of dementia (without autopsy confirmation) was obtained in half of the patients.

\section{Functional Aspects}

Functional independence levels were measured at the onset of the study using the Instrumental Activities of Daily Living Scale $^{14}$ and the Rapid Disability Rating Scale. ${ }^{15}$ Testing using the first scale reveals that 7 out of 9 patients cannot dial the telephone, 6 out of 7 need to be supervised for shopping, 4 out of 4 cannot prepare meals anymore, all must be accompanied outside the home and none can handle their own finances. Thus most subjects are dependent for adaptive tasks that they previously performed well. The data from the second scale is presented in Table 2. Here again adaptive tasks (telephone, money) are accomplished with difficulty. Dressing and grooming are the most affected skills followed by bathing. Total scores range from 11 to 15 and are congruent with the Global Deterioration Scale. ${ }^{13}$ Assessments using these scales are repeated at six weeks and at three and six months following surgery.

\section{Neuropsychological Testing}

The Mini Mental State ${ }^{12}$ is used to screen individuals, aiming at a performance between 10 and 24 on a scale of 30 , and is quite reproducible. The battery of cognitive tests chosen by the multi-centre trial group are as follows: (1) the digit symbol from WAIS, Boston naming, word fluency and selective word reminding are used every three weeks; (2) block design and digit span from WAIS, Weschler memory scale, trials $A$ and $B$ are administered preoperatively then six weeks, three months and six months postoperatively. The results of these tests will be reported by the multi-centre trial group at the end of the study.

\section{Laboratory Work-Up}

Beyond the usual laboratory work-up required to exclude other causes of dementia, we paid special interest to the EEG, CT and MRI because of their potential use in the diagnosis of Alzheimer's disease. As we reported recently ${ }^{16}$ and as our current data shows (Table 3), there are no features of these examinations specific for Alzheimer's disease. One patient (P.H.W.) had a photomyoclonic response on EEG, but another patient (M.B.R.), with clinical myoclonus, did not show that response. One MRI (P.H.W.) was felt to be compatible with Binswanger's disease because of high intensity periventricular signals (Figure 1) but she clearly had Alzheimer's disease on the cortical biopsy.

\section{Pump and Catheter Implantation}

The procedure is performed following endotracheal intubation and induction of general anesthesia. The patient is placed in the supine position with the head turned to the left. The scalp, neck, trunk and abdomen are shaved and disinfected using Hibitane solution (Ayerst), iodine and alcohol.

A $10 \mathrm{~cm}$ curvilinear incision is made over the right frontal area, behind the hairline, extending just lateral to the midline. Bleeding is controlled by diathermy and by mechanical clips applied to the scalp edges. The skin flap is retracted to expose the periosteum. A burr hole is placed 3 centimetres from the midline, 2 centimetres in front of the coronal suture. A small trephine craniotomy is performed, incorporating the burr hole at its medial edge. Bleeding from the middle table of the skull is controlled by the application of bone wax. A ventricular drain measuring 5-6 centimetres in length is inserted into the frontal horn of the right lateral ventricle. The ventricular drain is connected to a reservoir without valve. The dura is then opened in a cruciate fashion and a 1.5 to 2 centimetre square biopsy of the pre-frontal cortex is obtained. Bleeding is controlled using bipolar diathermy, oxidized regenerated cellulose and absorbable gelatin sponges. Attention is then given to the right lower quadrant of the abdomen where an 8 centimetre horizontal incision is made just below the level of the umbilicus. The incision is extended through the subcutaneous fat and the subcutaneous tissue is undermined to form a pocket that snugly accommodates the pump. The two operative sites are joined by a subcutaneous tunnel through which the tubing emanating from the pump is passed and connected to the reservoir. Prior to the final connection of the pump tubing to the reservoir, normal saline is injected into the side port of the pump to verify that the system is patent. The bone flap is returned into place and held by stainless steel wires. The galea is closed using 


\begin{tabular}{|c|c|c|c|c|c|c|c|c|}
\hline Patients & Sex & $\begin{array}{c}\text { Age at } \\
\text { Surgery }\end{array}$ & $\begin{array}{c}\text { Duration of } \\
\text { Disease (yrs) }\end{array}$ & M.M.S.* & G.D.S.** & $\begin{array}{c}\text { City/ } \\
\text { Province }\end{array}$ & Education & $\begin{array}{c}\text { Family HX } \\
\text { of Dementia }\end{array}$ \\
\hline M.B.R. & $\mathrm{F}$ & 43 & 2 & 18 & 4 & $\begin{array}{l}\text { Trois- } \\
\text { Rivières, } \\
\text { Québec }\end{array}$ & University & pos \\
\hline J.D.L. & $\mathrm{F}$ & 65 & 4 & 18 & 4 & $\begin{array}{l}\text { Béloeil, } \\
\text { Québec }\end{array}$ & Grade 7 & pos \\
\hline S.S. & $\mathbf{M}$ & 67 & 5 & 21 & 4 & $\begin{array}{l}\text { Montréal, } \\
\text { Québec }\end{array}$ & University & pos \\
\hline P.H.W. & F & 47 & 5 & 12 & 5 & $\begin{array}{l}\text { Orillia, } \\
\text { Ontario }\end{array}$ & College & neg \\
\hline A.K. & $\mathrm{M}$ & 64 & 2 & 19 & 4 & $\begin{array}{l}\text { Toronto, } \\
\text { Ontario }\end{array}$ & University & pos \\
\hline
\end{tabular}

* M.M.S. = Minimental state of Folstein, $1975(0=$ abnormal, $30=$ normal $)$

** G.D.S. = Global Deterioration Scale of Reisberg, $1982(1=$ normal, $7=$ severely abnormal $)$

Table 2: Assistance in Activities of Daily Living in Canadian Patients Treated with Intracerebroventricular Betanechol Infusion*

\begin{tabular}{|c|c|c|c|c|c|c|c|c|c|c|}
\hline Patients & Eating & Walking & Mobility & Bathing & Dressing & Toileting & Grooming & Adaptive Tasks & Total & G.D.S.*** \\
\hline M.B.R. & 1 & 1 & 1 & 1 & 1 & 1 & 2 & 3 & 11 & 4 \\
\hline J.D.L. & 1 & 1 & 1 & 1 & 2 & 1 & 1 & 3 & 11 & 4 \\
\hline S.S. & 1 & 1 & 1 & 1 & 2 & 1 & 2 & 3 & 12 & 4 \\
\hline B.M. & 1 & 1 & 1 & 1 & 2 & 1 & 1 & 4 & 12 & 4 \\
\hline P.H.W. & 2 & 1 & 1 & 2 & 2 & 1 & 2 & 4 & 15 & 5 \\
\hline A.K. & 1 & 1 & 1 & 2 & 2 & 1 & 1 & 2 & 11 & 4 \\
\hline
\end{tabular}

* Rapid Disability Rating Scale - II of Linn and Linn, 1982 ( $I=$ no assistance required, $4=$ completely dependent $)$

** G.D.S. = Global Deterioration Scale of Reisberg, $1982(1=$ normal, $7=$ severely abnormal $)$

absorbable suture material and the scalp is closed with 4.0 nylon. The abdominal incision is similarly closed. Bacitracin is infiltrated into both wounds, dry dressings are applied, and the patient is brought to the Recovery Room.

Moderate to severe cortical atrophy was observed in all patients. Cerebral amyloid angiopathy was evident at the time of cortical biopsy and was confirmed histologically (Figure 2). Relatively difficult hemostasis occurred frequently due to poorly contractile arterial vessels in which the contractile elements have been replaced by amyloid. ${ }^{17}$ However, with meticulous diathermy and with the application of oxidative reconstituted cellulose and small pieces of absorbable gelatin sponges postoperative hemorrhage has not been encountered.

The patients are mobilized as soon as possible. The dressings are changed at 24 hours and every two days subsequently. The sutures are removed between the seventh and ninth day depend- ing upon the quality of wound healing. Corticosteroids are not routinely used. Post-operative CT scans and $x$-rays of the skull, chest and abdomen are obtained to verify proper positioning of the system (Figure 3a, 3b).

Some patients undergoing surgery have had evidence of pneumocephalus in the postoperative phase. This results from collapse of the brain at the time of dural opening and is directly related to the degree of cerebral atrophy present. Generally, this is of no clinical importance. However, the procedure had to be aborted on one occasion because of this occurrence; another patient was kept on bed rest post-operatively while awaiting brain re-expansion.

\section{Cortical Biopsies}

The cortex was dissected from white matter immediately after resection. Cortical fragments were snap frozen and stored 
Table 3: Laboratory Features of Canadian Patients Treated with Intracerebroventricular Bethanechol Infusion

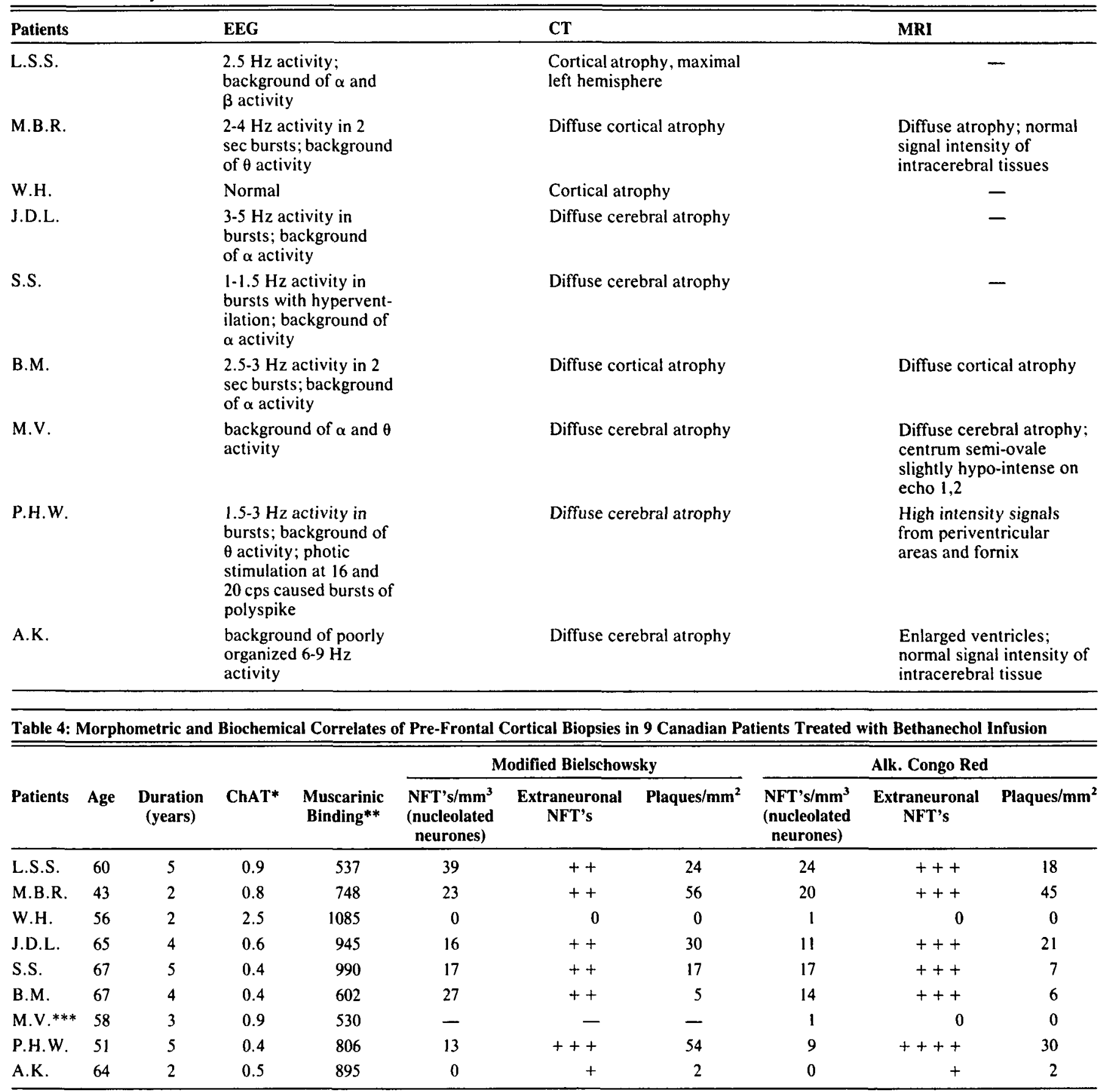

${ }^{*}$ ChAT $=$ Choline Acetyltransferase activity, normal range $2.4 \pm 0.2 \mathrm{nmol} / \mathrm{mg}$ protein $/$ hour

** B max using $\left({ }^{3} \mathrm{H}\right) \mathrm{QNB}$, normal range $1188 \pm 124 \mathrm{fmol} / \mathrm{mg}$ protein

***MV patient's tissue blocks were exhausted. Modified Bielschowsky stain could not be done

at $-80^{\circ} \mathrm{C}$ for biochemistry. Others were diced into $0.1 \mathrm{~cm}^{2}$ fragments and fixed in $3 \%$ glutaraldehyde for electron microscopy. Cortical and white matter fragments were fixed in buffered $10 \%$ formalin for routine histopathology. Paraffinembedded fragments were step-sectioned into a minimum of 20 sections, which were alternately stained with haematoxylineosin, Kluver Barrera, alkaline Congo Red, modified Bielschowsky and Holmes' silver stains. Glutaraldehyde-fixed specimens were handled according to standard electron microscopic techniques and examined with a JEOL 100 CXII transmission microscope.
Morphometric histopathological data were gathered with a graticule-fitted Leitz Dialux microscope. Neurofibrillary tangles and senile plaque indexes were tabulated on both modified Bielschowsky and polarized alkaline Congo Red stains. For neurofibrillary tangles, only those intracytoplasmic tangles visualized within nucleolated neurones were counted. Other tangles in the neuropil and salient electron microscopic features were semiquantitatively assessed on a scale of + to ++++ .

Histopathological criteria for inclusion within the "definite Alzheimer" group were neurofibrillary tangle (NFT) and senile plaque (SP) indexes of at least $20 / \mathrm{mm}^{3}$ and $10 / \mathrm{mm}^{2}$ respectively. ${ }^{18}$ 
Table 5: Summary of Salient Electronmicroscopic Features in Pre-Frontal Cortical Biopsies of 9 Canadian Patients Treated with Betanechol Infusions

\begin{tabular}{lcrr}
\hline \hline Patients & $\begin{array}{c}\text { Paired Helical } \\
\text { Filaments }\end{array}$ & $\begin{array}{c}\text { Intra-Synaptic Paired } \\
\text { Helical Filaments }\end{array}$ & $\begin{array}{c}\text { Straight } \\
\text { Filaments }\end{array}$ \\
\hline L.S.S. & ++++ & ++ & + \\
M.B.R. & ++++ & + & + \\
W.H. & ++++ & ++ & ++ \\
J.D.L. & ++++ & ++ & + \\
S.S. & ++++ & + & + \\
B.M. & ++++ & ++ & + \\
M.V. & + & + \\
P.H.W. & (with micro- & + \\
A.K. & tubular & + \\
& arrays) & +
\end{tabular}

Accordingly, six of the nine patients included in the study could be histopathologically classified within the "definite Alzheimer" group. Comparison of results derived from modified Bielschowsky and alkaline Congo Red stains (Table 4) showed the former to be a significantly more sensitive preparation for morphometry. Using data obtained from modified Bielschowsky stains in those patients histologically diagnosed as "definite Alzheimer", the NFT index provided a significant correlation with Mini Mental state scores $(r=0.8507)$, however, the SP index showed no significant correlation $(r=0.3362$; Figure $4 a)$. This correlation is still significant for the NFT index $(r=0.8570$; Figure 4b) if two sub-diagnostic patients with low cortical ChAT values are added in the calculations. Significant correlations of NFT and SP indexes could be established with the duration of clinical symptoms as determined by the date of onset of neurological abnormalities $(r=0.7530 ; r=0.4764$, Figure 5). Semi-quantitative estimates of neuropil NFT indexes, ultrastructural intrasynaptic involvement by NFT's (Figure 6) and paired neurofilament densities were markedly increased in all patients included in the histopathological "definite Alzheimer" group. All patients fulfilling histopathological criteria for Alzheimer's disease displayed mild to moderate amounts of neuronal loss which predominated in laminae 2 and 3 and conspicuous intravascular deposits of amyloid (Figure 2).

Two patients who displayed significantly decreased cortical ChAT values without significant increases of NFT and SP indexes showed high densities of intraneuritic straight neurofilaments with very few paired helical filamentous profiles (Figure 7). One (A.K.) actually displayed $24 \mathrm{~nm}$ wide microtubular arrays in few cortical neurones (Figure 8). One patient (W.H.) could not be reliably classified within any specific diagnostic group in view of the lack of significant changes observed in both biochemical and morphometric parameters, except for increased intraneuritic straight neurofilaments on electron microscopic examination. Except for this patient, all ChAT values were as low as those obtained from post-mortem material. Muscarinic binding was heterogenous among patients and will need to be correlated with the clinical response to bethanechol infusion at the end of the study. The correlation between the NFT index vs muscarinic binding was very strong $(r=0.9150)$, but was weaker with the SP index ( $r=0.4878$; Figure 9).

\section{Clinical Course}

All patients were admitted at the Montreal Neurological Institute for their surgery, many sharing their rooms with a relative. This lessened the incidence of pre- and post-operative confusion. In those nine patients there was only one focal seizure on day 5 post op, treated with phenytoin. No hemor-

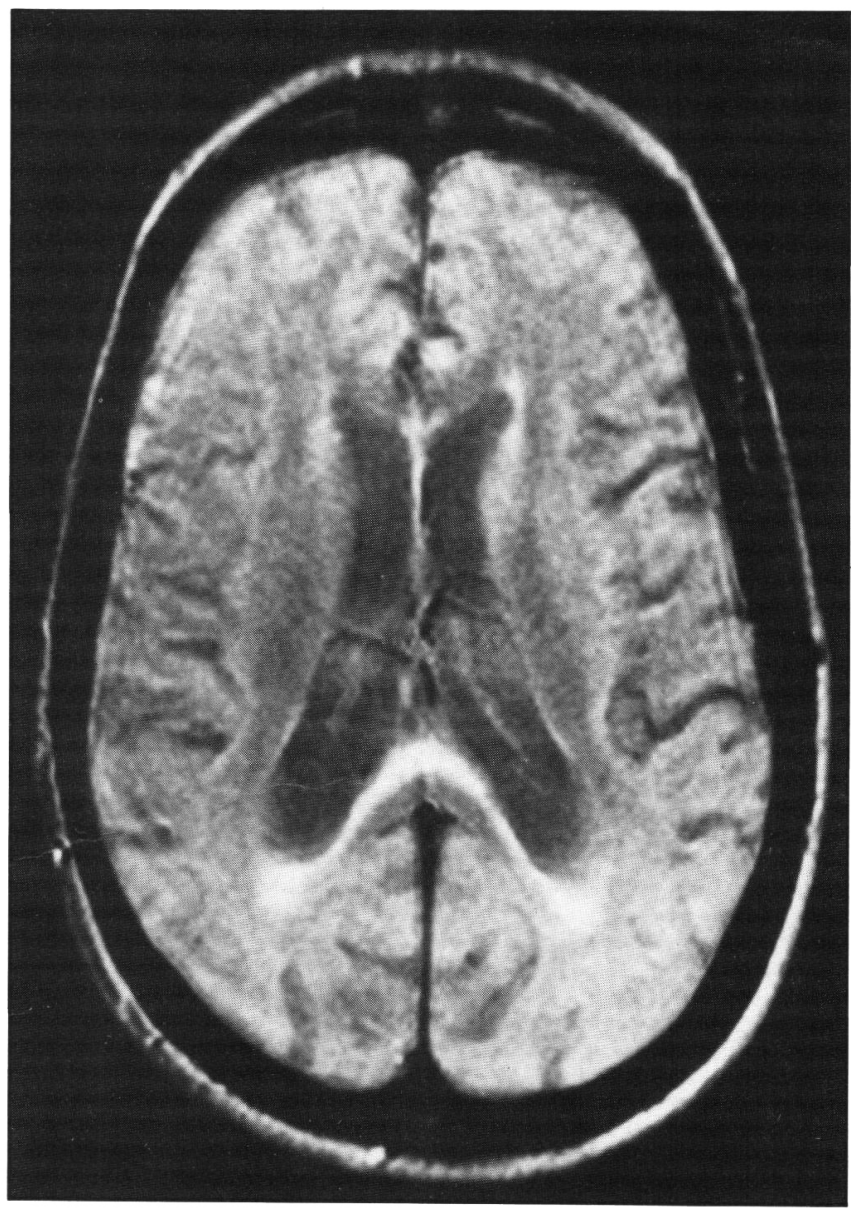

Figure I - MRI scan of patient P.H.W. spin echo I, read as "compatible with Binswanger's disease" , but clearly showing Alzheimer pathological features on biopsy. 


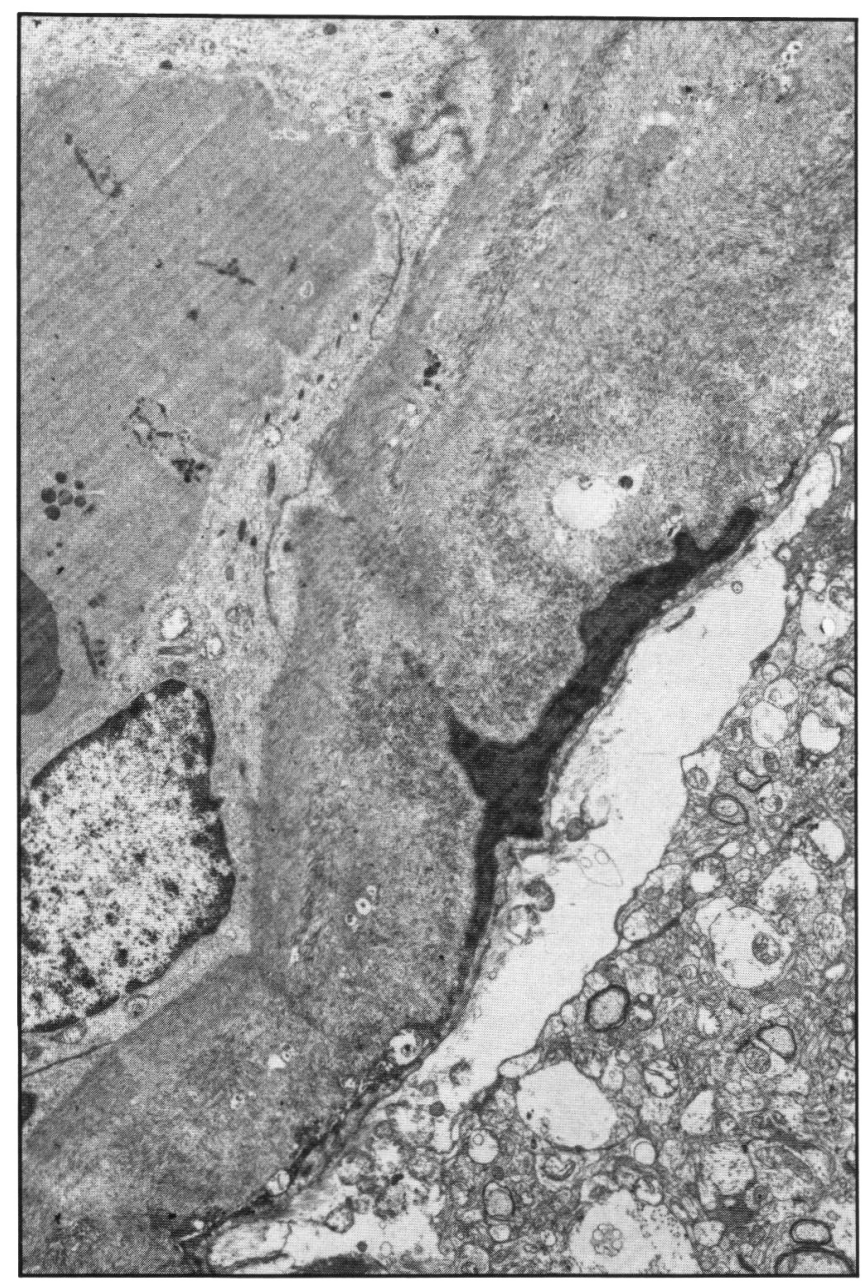

Figure $2-X 2,700$ Small cortical vein infiltrated by 20 to $40 \mathrm{~nm}$ wide fibrils characteristic of amyloid. The basement membrane is thickened and pericytes appear to have phagocytosed amyloid. Patient B.M.

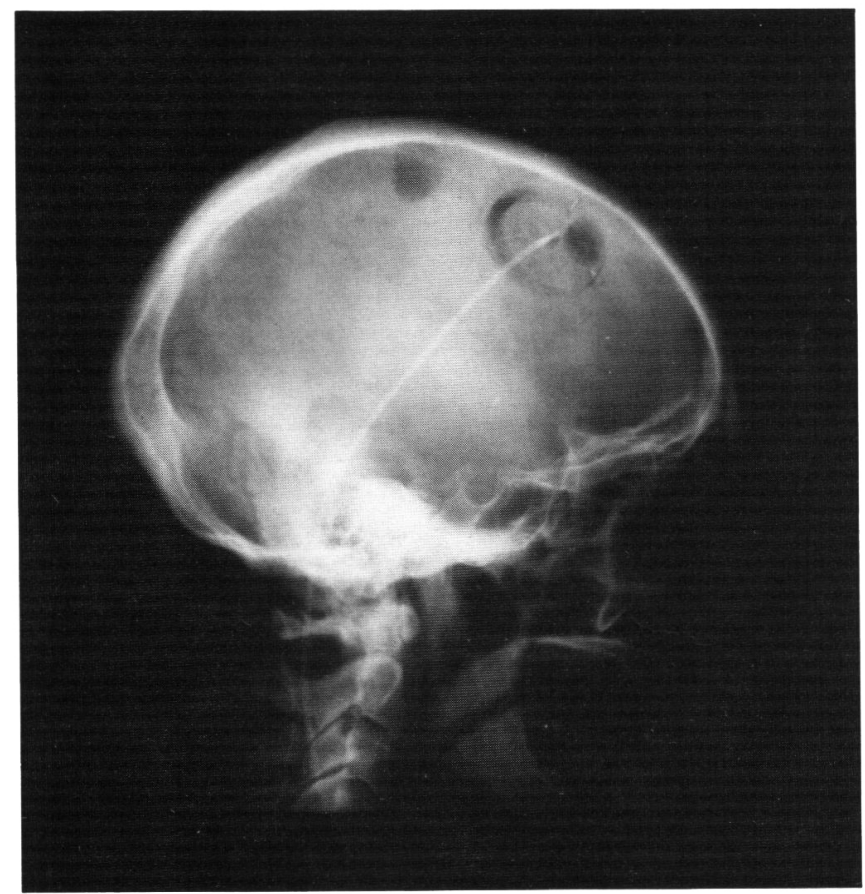

Figure $3 a-S k u l l X$-ray after ventricular catheter placement.

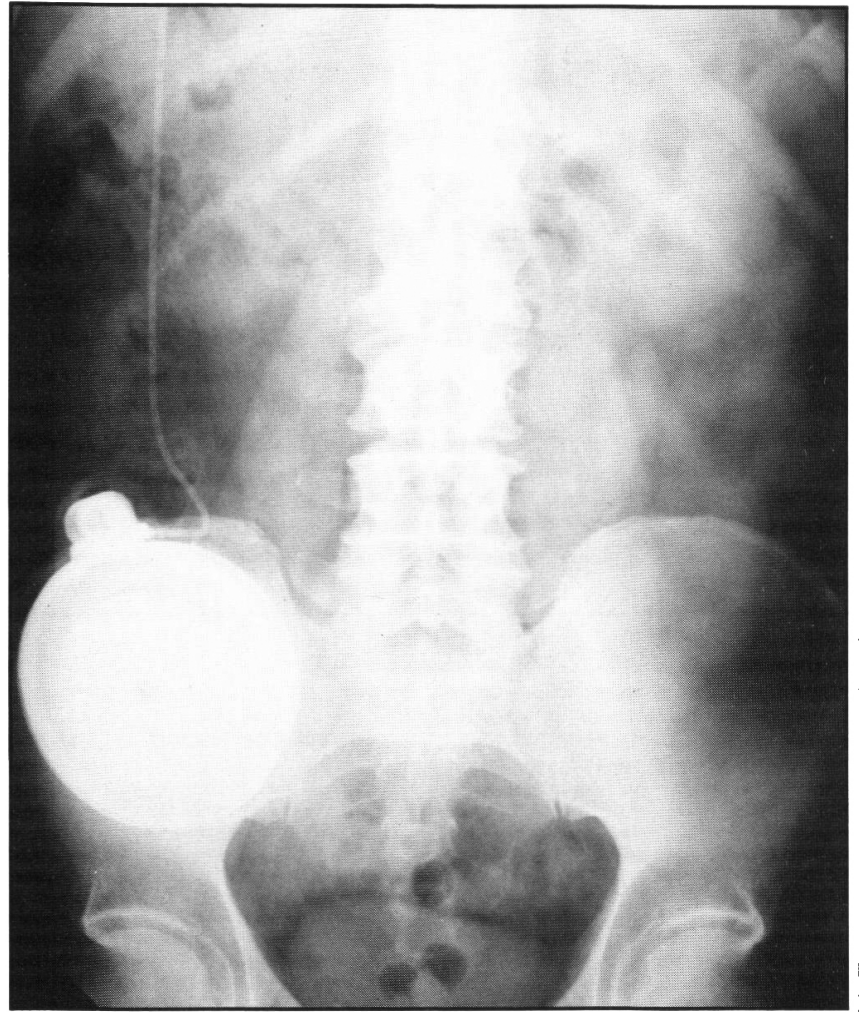

Figure $3 b-$ Abdominal X-ray showing the Intermedics Infusaid Inc. pump located subcutaneously in the right inferior quadrant.

rhage occurred despite the congophilic angiopathy seen on biopsy.

The Infusaid pump model 400 is refilled every three weeks by trans-cutaneous puncture at which time neuropsychological tests and functional assessments are made. Transient nausea occurs in some patients after pump refill. Some families are spontaneously looking for stimulation strategies such as children's books and illustrated dictionaries.

\section{Discussion}

The morphological and morphometric data gathered in our study differ from those of Neary et al ${ }^{19}$ who, in a large series of demented patients submitted to temporal lobe biopsy, showed weak correlations of neuronal loss and NFT indexes with deterioration of cognitive function as determined by the Mini Mental State. Two of our patients did not fulfill histopathological criteria for inclusion within the "definite Alzheimer"' group. They nonetheless had significantly decreased cortical ChAT values. In the "definite" cases, NFT and SP indexes could be correlated with duration of symptoms (Figure 5). Our data thus suggests that the rate of Alzheimerization, particularly as determined by the NFT index, varies markedly from patient to patient. In this context, the onset of pre-frontal cortex morphological stigmata would represent a late manifestation of Alzheimer's disease. This is consistent with Positron Emission Tomography (PET) data showing a predominance of fluorodeoxyglucose hypometabolism in the parietal cortex in the early phase of Alzheimer's disease. ${ }^{20}$

We therefore suspect that patients receiving bethanechol infusion who will benefit the least are those with low Mini 
Correlation of NFT and Plaque Indexes in Pre-frontal Cortical Biopsies Fulfiling Mistopathological Criteria lor AD/SDAT with Mini Mental State Score (Modified Bielschowsky)

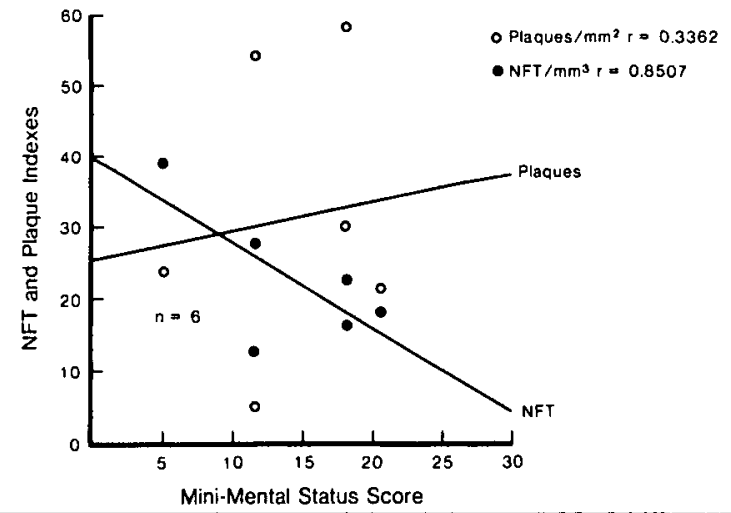

Figure $4 a-$ Correlations between NFT and SP indexes and Mini Mental State. $N=6$.

Correlation of MFT and Plaque Indexes with

Mini Mental State Scores in 8 Demented Patients

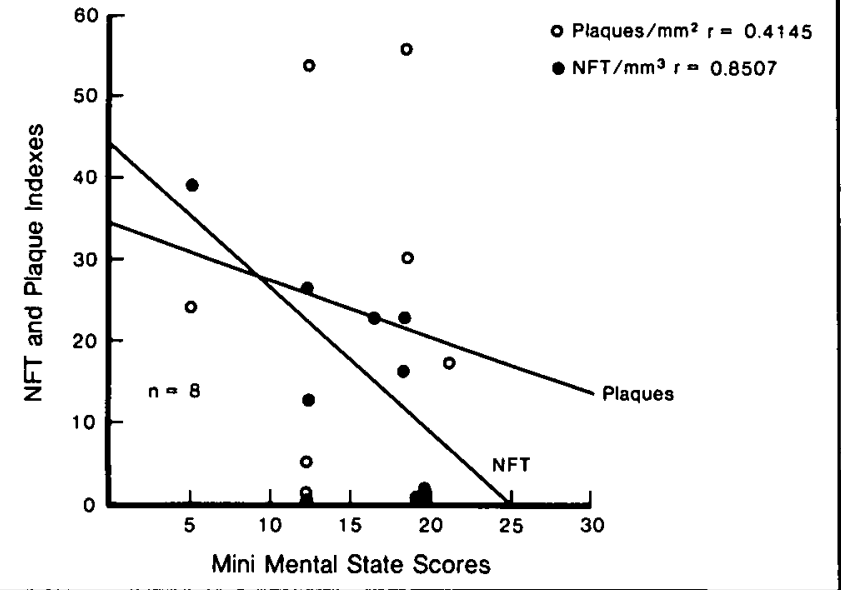

Figure $4 b-$ Correlations between NFT and SP indexes and Mini Metal State. $N=8$.

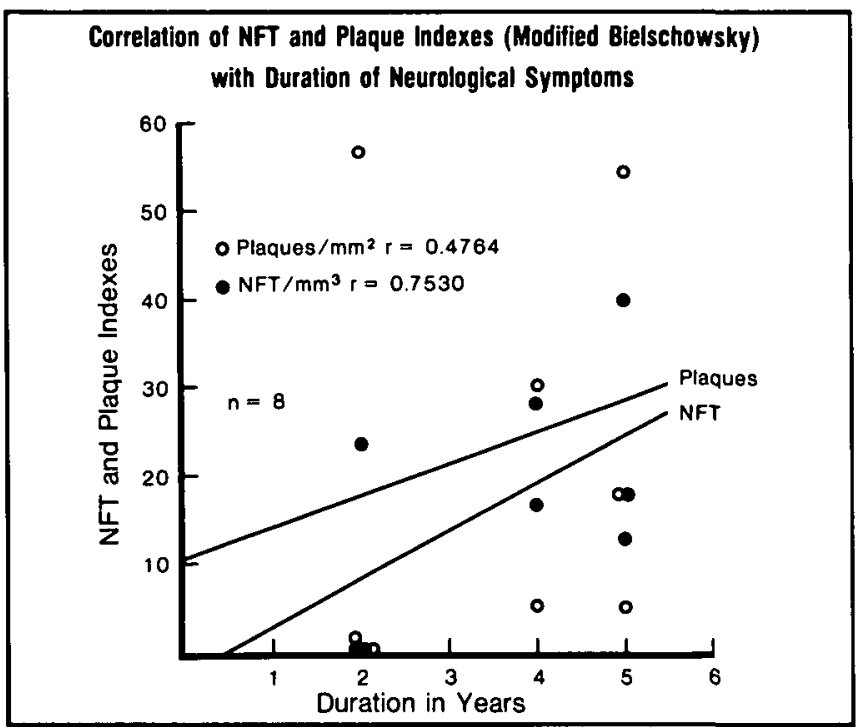

Figure 5 - Correlations between NFT and SP indexes and duration of clinical symptoms.
Mental State score and high NFT indexes, since these abnormalities are correlated with a high incidence of intrasynapticpaired helical filaments and low muscarinic binding. Conversely, patients with a sub-diagnostic threshold NFT index and a high incidence of intraneuritic straight neurofilaments may benefit from bethanechol infusion.

For those who will fail to improve on bethanechol infusion somatostatin replacement therapy may be an alternative. Somatostatin (SRIH) receptors have been well described within human cortex ${ }^{21}$ and SRIH concentrations are low in the $\mathrm{CSF}^{22}$ and in the frontal and temporal corte ${ }^{23,24}$ of patients with Alzheimer's disease. The functional role of this transmitter is not yet clear, ${ }^{25}$ but loss of SRIH in the parietal cortex has been correlated to fluoro-deoxyglucose hypometabolism. ${ }^{26}$ The presence of paired helical filaments in SRIH positive cell bodies implicates these neurons in the primary disease process. ${ }^{2}$

Early attempts to intravenously replace SRIH using an analog have failed. ${ }^{27} \mathrm{We}$ are exploring the feasibility of continuous cisterna magna infusion of the SRIH analog Sandostatin ${ }^{R}$ by testing its stability in the Infusaid pump and by documenting the presence or absence of behavioral and metabolic toxicity in

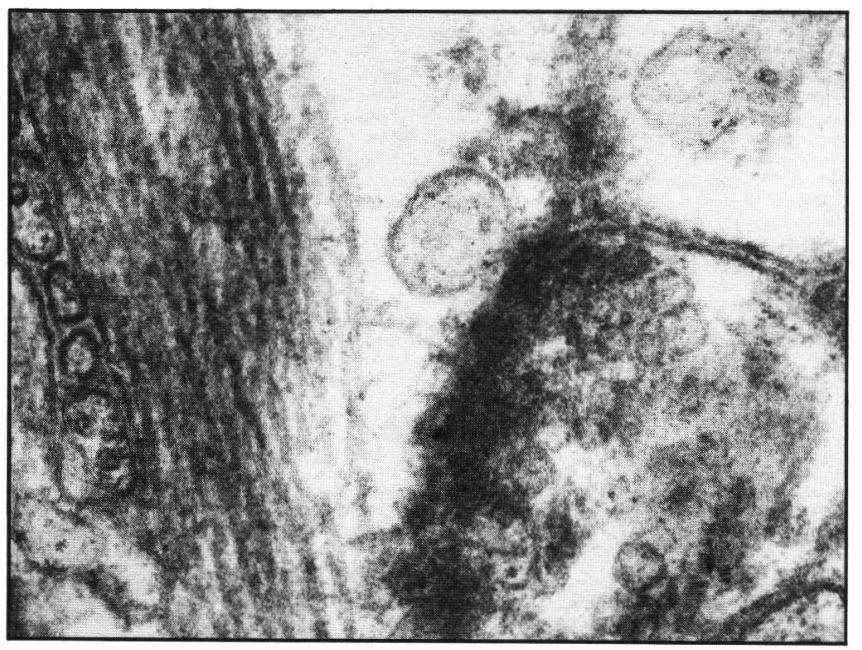

Figure $6-X 80,000$ Post-synaptic structure is partly replaced by paired helical filaments showing $80 \mathrm{~nm}$ periodicity.

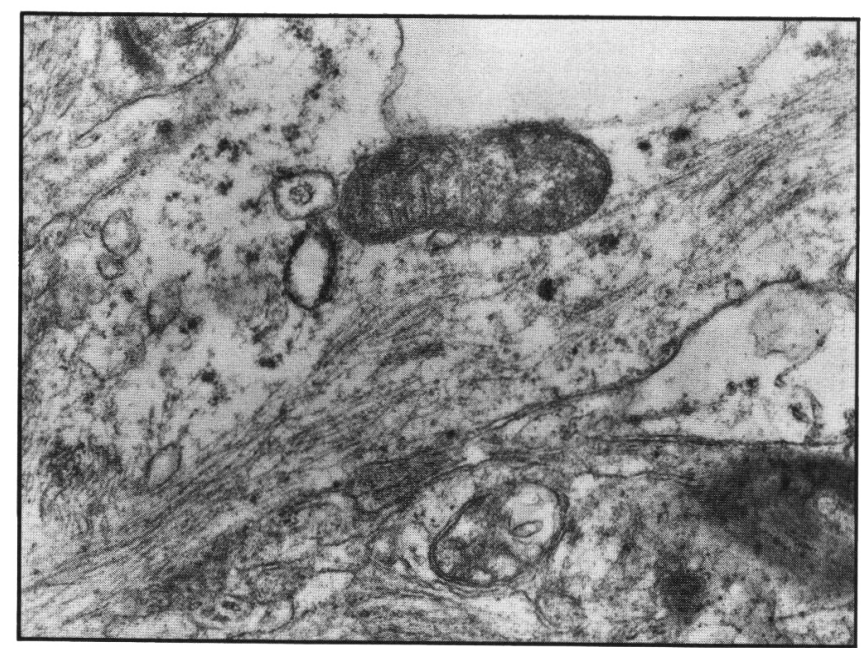

Figure 7-X 27,000 Intra-axonal aggregates of $12 \mathrm{~nm}$ wide straight neurofilaments. Patient M.V. 
the monkey. SRIH has already been infused safely in man via the spinal intrathecal route for control of intractable pain. ${ }^{28}$ There is thus a realistic hope of testing its therapeutic value in Alzheimer's disease in the near future.

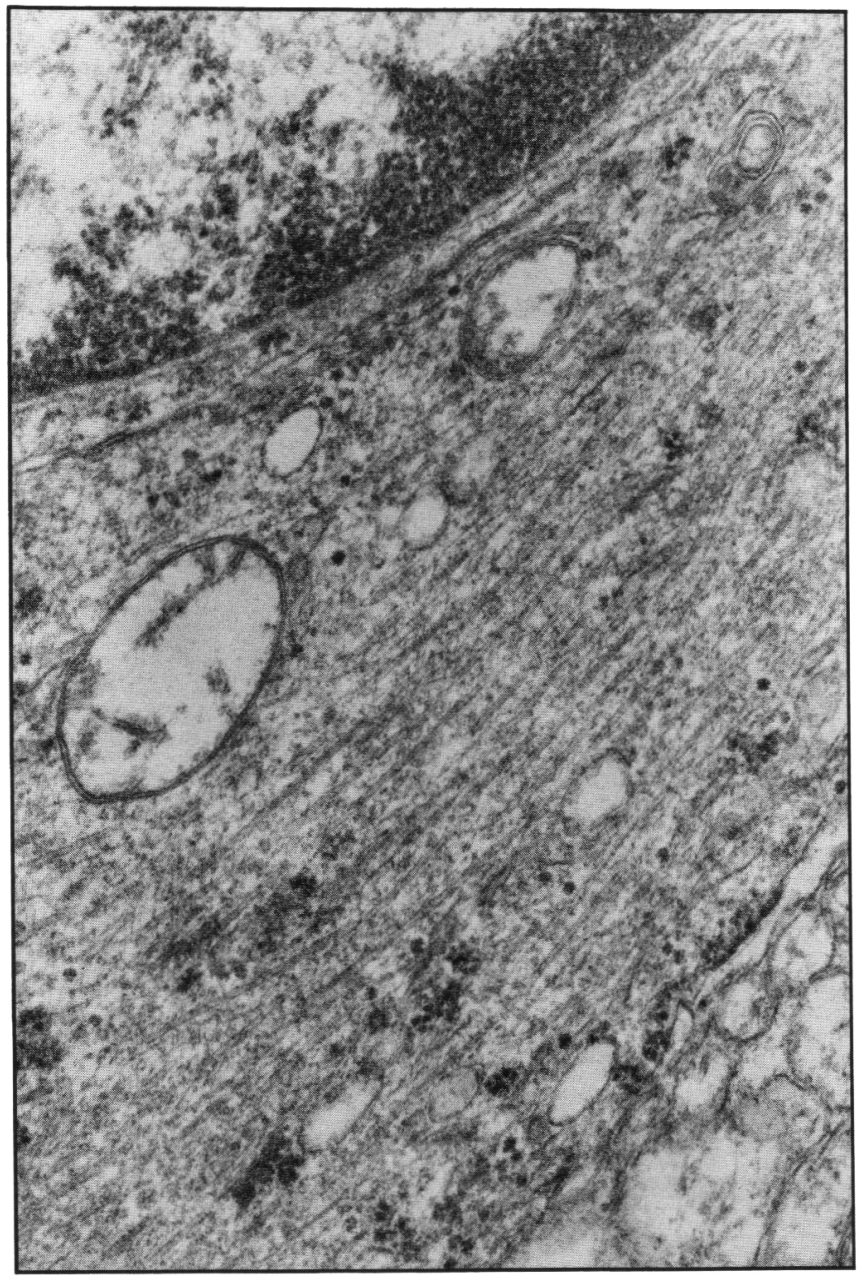

Figure $8-X 27,000$ Intracytoplasmic arrays of $24 \mathrm{~nm}$ wide microtubules Patient A.K.

Correlatton of NFT and Plaque Indexes with Cortical Muscarinic Binding

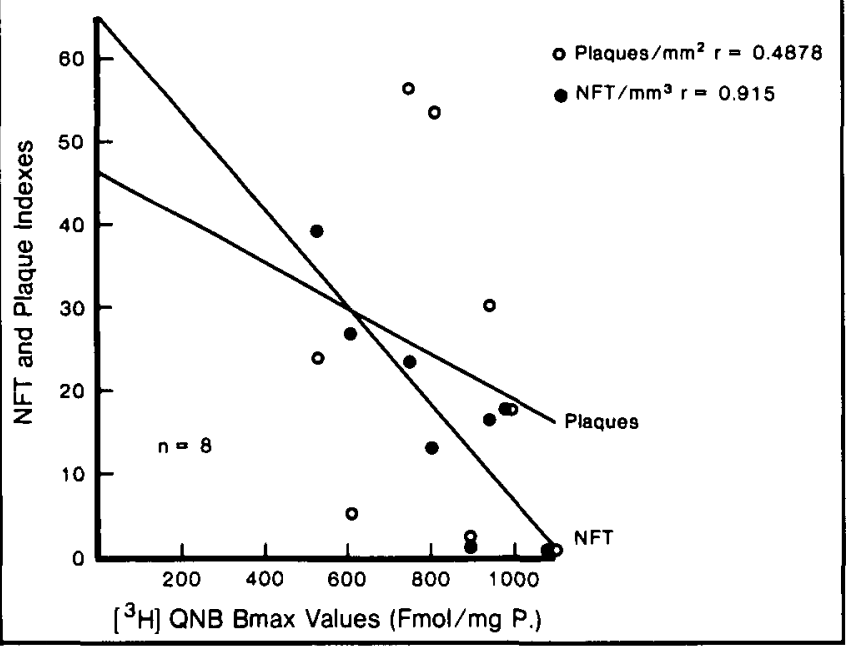

Figure 9 - Correlations betweenNFT and SP indexes and muscarinic binding.

\section{Conclusion}

There is cautious optimism that transmitter replacement therapy using ICV infusion may be feasible and useful in Alzheimer's disease. It is already clear that cortical biopsy is essential to the basic understanding of the disease and may be useful in predicting drug response.

\section{ACKNOWLEDGEMENTS}

We thank Infusaid Corporation and Sandoz Canada for their financial support, our MNH nursing staff for the excellent care of our patients, our hospital pharmacists and psychologists for their professionalism and our technical and secretarial staff for their high quality work. Special thanks to Kevin Kemball for able assistance with statistical analysis, Steve Blagrave for providing skillful assistance with histopathological techniques and Beverely Lindsay for excellent typing skills.

\section{REFERENCES}

1. Whitehouse PJ, Price DL, Struble RG, et al. Alzheimer's disease and senile dementia: Loss of neurons in the basal forebrain. Science 1982; 215: 1237-1239.

2. Roberts GW, Crow TJ, Polak JM. Location of neuronal tangles in somatostatin neurones in Alzheimer's disease. Nature 1985; 314: 92-94

3. Yamamoto T, Hirano A. Nucleus raphe dorsalis in Alzheimer's disease: Neurofibrillary tangles and loss of large neurons. Ann Neurol 1985; 17: 573-577.

4. Perry EK, Tomlinson BE, Blessed G, et al. Neuropathological and biochemical observations on the noradrenergic system in $\mathrm{Alz}$ heimer's disease. J Neurol Sci 1981; 51: 279-287.

5. De Souza EB, Whitehouse PJ, Kuhar MJ, et al. Reciprocal changes in corticotropin-releasing factor (CRF)-like immunoreactivity and CRF receptors in cerebral cortex of Alzheimer's disease. Nature 1986; 319: 593-595.

6. Etienne P, Gauthier S, Johnson G, et al. Clinical effects of choline in Alzheimer's disease. Lancet 1978; 1: 508.

7. Etienne P, Dastoor D, Gauthier S, et al. Alzheimer disease: Lack of effect of lecithin treatment for 3 months. Neurology 1981; 31: 1552-1554.

8. Caltagirone C, GainottiG, Masullo C. Oral administration of chronic physostigmine does not improve cognitive or mnesic performances in Alzheimer's presenile dementia. Int J Neurosci 1982; 16: $247-249$

9. Davous P, Lamour Y. Bethanechol decreases reaction time in senile dementia of the Alzheimer type. J Neurol Neurosurg Psychiatry 1985; 48: 1297-1299.

10. Harbaugh RE, Roberts DW, Coombs DW, et al. Preliminary report: Intracranial cholinergic drug infusion in patients with Alzheimer's disease. Neurosurgery 1984; 15: 514-518.

11. McKhann G, Drachman D, Folstein M, et al. Clinical diagnosis of Alzheimer's disease: Report of the NINCDS-ADRDA Work Group under the auspices of Department of Health and Human Services Task Force on Alzheimer's Disease. Neurology 1984; 34: 939-944.

12. Folstein MF, Folstein SE, McHugh PR. "Mini-Mental State" A practical method for grading the cognitive state of patients for the clinician. J Psychiat Res 1975; 12: 189-198.

13. Reisberg B, Ferris SH, de Leon MJ, et al. The global deterioration scale (GDS): An instrument for the assessment of primary degenerative dementia. Am J Psychiat 1982; 139: 1136-1139.

14. Lawton MP, Brody EM. Assessment of older people: Self-maintaining and instrumental activities of daily living. Gerontologist 1969; 9: 179-186.

15. Linn MW, Linn BS. The rapid disability rating scale - II. J Amer Ger Soc 1982; 30: 378-382.

16. Gauthier S, Robitaille Y, Quirion R, et al. Antemortem laboratory diagnosis of Alzheimer's disease. Prog Neuro-Psychopharmacol and Biol Psychiat 1986; 10: (in press). 
17. Cosgrove GR, Leblanc $R$, Meagher-Villemure $K$, et al. Cerebral amyloid angiopathy. Neurology 1985; 35: 625-631.

18. Ball MJ. Neuronal loss, neurofibrillary tangles and granulovacuolar degeneration in the hippocampus with ageing and dementia. Acta Neuropath 1977; 37: 111-118.

19. Neary D, Snowden JS, Mann DMA, et al. Alzheimer's disease: a correlative study. J Neurol Neurosurg Psychiatry 1986; 49: 229-237.

20. Friedland RP, Budinger TF, Brant-Zawadzki M, et al. The diagnosis of Alzheimer-type dementia. A preliminary comparison of positron emission tomography and proton magnetic resonance. JAMA 1984; 252: 2750-2752.

21. Uhl GR, Tran V, Snyder SH, et al. Somastostatin receptors: Distribution in rat central nervous system and human frontal cortex. J Comp Neurol 1985; 240: 288-304.

22. Wood PL, Etienne P, Lal S, et al. Reduced lumbar CSF somatostatin levels in Alzheimer's disease. Life Sci 1982; 31: 2073-2079.
23. Davies P, Katzman R, Terry RD. Reduced somatostatin-like immunoreactivity in cerebral cortex from cases of Alzheimer disease and Alzheimer senile dementia. Nature 1980; 288; 279-280.

24. Beal MF, Mazurek MF, Tran VT, et al. Reduced numbers of somatostatin receptors in the cerebral cortex in Alzheimer's disease. Science 1985; 229: 289-291.

25. Beal MF, Uhl G, Mazurek MF, et al. Somatostatin: Alterations in the central nervous system in neurological diseases. I $n$ : Martin JB, Barchas JD, eds. Neuropeptides in Neurologic and Psychiatric Disease. New York: Raven Press, 1986: 215-257.

26. Tamminga CA, Tanimoto K, Foster NL, et al. Alzheimer's disease: Somatostatin loss in area of maximal fluorodeoxyglucose reduction. Neurology 1985; 35 (Suppl 1): 183.

27. Cutler NR, Haxby JV, May C, et al. L-363,586, a somatostatin analog: An assessment of memory function in Alzheimer's disease. Neurology 1985; 35 (Suppl 1): 265.

28. Meynadier J, Chrubasik J, Dubar M, et al. Intrathecal somatostatin in terminally ill patients. A report of two cases. Pain 1985; 23: 9-12. 